\title{
Who are believers in religion in China?
}

Link to publication record in Manchester Research Explorer

\section{Citation for published version (APA):}

Li, Y., Lu, U., X., O., Leary, U., R, U., Y., U., \& Day, A. (Ed.) (2008). Who are believers in religion in China? In Religion and the Individual (pp. 47-61). Ashgate Publishing .

\section{Published in:}

Religion and the Individual

\section{Citing this paper}

Please note that where the full-text provided on Manchester Research Explorer is the Author Accepted Manuscript or Proof version this may differ from the final Published version. If citing, it is advised that you check and use the publisher's definitive version.

\section{General rights}

Copyright and moral rights for the publications made accessible in the Research Explorer are retained by the authors and/or other copyright owners and it is a condition of accessing publications that users recognise and abide by the legal requirements associated with these rights.

\section{Takedown policy}

If you believe that this document breaches copyright please refer to the University of Manchester's Takedown Procedures [http://man.ac.uk/04Y6Bo] or contact uml.scholarlycommunications@manchester.ac.uk providing relevant details, so we can investigate your claim.

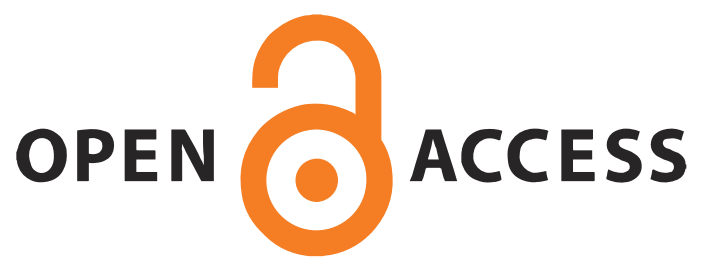




\title{
Chapter Four
}

\section{Who are the Believers in Religion in China?}

\author{
Xiaowen Lu, Richard O'Leary and Yaojun Li
}

\section{Introduction}

While it is widely accepted that there has been a revival of religious belief in postMao China, so far there is still relatively little known about this development. Sociologists and others have documented the changes in the laws and state regulation pertaining to religion (Yang 2006; Leung 2005; Potter 2003) and have provided accounts of religious practices and beliefs based on field research (for example, Dean 2003 on popular religion; Madsen 1998 on Catholics; Hunter and Chan 1993 on Protestants). However, to date there has been a lack of research based on national random sample surveys which could provide a firmer basis for generalization. The development of nationwide survey-based research has been hampered by both the relative underdevelopment of survey research generally in China and the inhibition about conducting empirical research on the sensitive topic of religion. Those survey findings about religion which have recently emerged have tended to lend themselves to superficial, sensationalist media headlines about the number of believers, devoid of critical interpretation. Furthermore, they have been limited to reporting simple percentages and have not proceeded to multivariate statistical analysis. In this chapter we attempt to rectify this by presenting some important new findings about religion in contemporary China that are based on multivariate statistical analysis of national random sample survey data.

Our research focus in on the specific question of who are the believers in religion in China. Our starting point needs to be how we interpret what Chinese mean by the self-description 'believer in religion'. Our initial research finding will be a report on the number of self-reporting believers in religion in China. Our main empirical results pertain to the multivariate statistical analysis which examines the sociodemographic and other individual characteristics associated with believing in religion. We locate this analysis within the broad theoretical framework of modernization and secularization and their application to the study of religion in contemporary China. Before we do this it will be helpful to our readers if we present the context for the study of believing in religion in present-day China. Of particular relevance are the legal status, and the meaning, of believing in religion. 


\section{The Legal Status of Believing in Religion}

In the post-Mao period, the principal law affecting religion has been the provisions of Article 36 of the 1982 constitution. These state:

Citizens of the People's Republic of China enjoy freedom of religious belief.

and

No state organ, public organization or individual may compel citizens to believe in, or not to believe in, any religion: nor may they discriminate against citizens who believe in, or do not believe in any religion. (PRC Constitution 1982)

While the freedom to believe in religion is protected under the law, the state is not indifferent to religious belief as the ruling Communist Party is explicitly atheistic. In accordance with traditional Marxist theory, religion is at best frowned upon and is supposed to gradually disappear as the socialist development progresses. In the view of one academic commentator, the Communist Party policy has privileged the freedom not to believe in religion and has used its control over the educational system to marginalize religious belief (Potter 2003, 14).

The state also distinguishes between what it views as legitimate religious activities and illegitimate activities which disrupt social order; and it only protects what it describes as normal religious activities. The Constitution specifies that no one may make use of religion to engage in activities that disrupt public order, impair the health of citizens or interfere with the educational system of the state. The Religious Affairs Bureau monitors the activities of all religions from the local to the national level. The practice of religion is legally confined to designated public places which can more easily be monitored. The government has suppressed some heterodox Christian and Qigong sects (Yang 2006). However, at times even some Protestant and Catholics centres of worship, their clergy or members have been censured by the Religious Affairs Bureau. This is typically related to unregistered 'house church' Protestants or Catholics operating outside the designated state-sponsored religious organizations. Potter $(2003,11)$ has summed up the situation for religious belief under the post-Mao government as permitting limited freedom of religious belief, subject to legal and regulatory restrictions on religious behaviour.

\section{The Meaning of 'Believe in Religion'}

The freedom to believe in religion described above refers to government-approved forms of five major traditions - Buddhism, Taoism, Catholic and Protestant Christianity, and Islam. This does not include independent groups of these traditions or traditional Chinese folk religion - the latter being viewed by the Communist Party as 'feudal superstition' and unworthy of recognition (Overmyer 2003, 2). In the questionnaire upon which our study is based, the question 'Ni xing jiao ma?' is translated as 'Do you believe in religion?'. Our interpretation of the responses to this question should consider the issues of the limitations of the Chinese word 'jiao' to 
describe religion and the exclusion of folk religion, the imprecision of membership of religions in China and the syncretic nature of much of Chinese religious belief.

Sun $(2005,232)$ reminds us that historically the term 'jiao' meant teachings rather than religion and that common references to the three teachings or 'san jiao' referred to Buddhism, Taoism and Confucianism. Sun elaborates how more recent usage of 'jiao' as 'religion' began in the twentieth century when jiao became a component of the newer term zongjiao to describe 'religion'. According to Dean (2003, 32), Western definitions of religion (including Marxist) tend to focus on features of religion which exclude much of Chinese religiosity. These are features such as religious doctrine, institutional organization, a hierarchical priesthood and rites that express particular beliefs. Dean reminds us that in China local communal religion, or 'popular religion' is very diverse in terms of its organization, includes multiple deities and does not always take the form of a clearly recognizable doctrine. In his view the narrow official definition of religion does not readily apply to "popular religion' as practised by millions of people in China.

There is in any case a difference between Western and Chinese notions of membership of a religion. Some respondents in a survey may not claim to believe in religion but upon further probing may reveal some religious beliefs. Under-reporting of this type has been found in surveys among the Chinese in Taiwan (Zhang and Lin 1992, 102; reported in Lu 2005, 182). Unlike Christianity, which emphasizes clearly defined membership of a single religion and encourages declarations of belief and the rituals of membership such as baptism, the traditional Chinese religions do not emphasize definite and exclusive membership. Not only can Chinese temples house a mix of deities from Taoism and Buddhism but persons may worship at multiple temples (Lang et al. 2005). The syncretism of Chinese religions is such that for many people there is no clear boundary between Buddhism, Taoism and the beliefs and practices of folk religion (Liu 2003). The notion of membership and of believing in religion is additionally complicated for China's ethnic minorities. For example, for ethno-religious minorities such as the Muslim Hui, their Hui ethnic identity is inherited, but not all may choose to describe themselves as believers in religion (Islam).

\section{Individual Characteristics Associated with Reported Belief in Religion}

There are now a number of qualitative studies of religious believers in China (see for example, Fan 2003 on folk religion; Aikman 2003 on Protestants; Lozada 2001 on Catholics). A strength of qualitative studies is that they provide valuable ethnographic material and offer some insights into the characteristics of believers in religion, in small localities or among particular congregations. However, there are not in existence - and it is unlikely there ever will be - sufficient local studies to piece together a national overview of believers in religion. Furthermore, small-scale studies which are not intended to be a basis for generalization may nevertheless have coloured our perception of the characteristics of believers in religion. Nationwide research based on random sample surveys can also complement the qualitative research and provide confirmation of or correction to some of the insights. 
First, we examine a range of individual characteristics which the literature has suggested may be associated with being a believer in religion in China. We then attempt to make sense of the effect of these characteristics in terms of the framework of modernization and concomitant secularization. This framework has been widely applied to the study of religion in Western industrial societies, and proposes that religion declines with advancing modernization (Wilson 1982; Wallis and Bruce 1992). Modernization is typically presented as a process effecting secularization but this thesis has been hotly debated and criticized (see Bruce 1992; Crockett and O'Leary 2004, O'Leary 2004) including when it is applied to Asian societies (Overmyer 2003,4). There is an additional dimension in China, in that the Christian religion in particular is perceived as being associated with modern Western societies, which may add to its appeal. Nevertheless, despite criticisms, the modernizationsecularization framework generates clear hypotheses which can be tested for contemporary China.

The concept of modernization is used to describe a society in terms of economic growth, industrialization, changing occupational structure, and the expansion of education, institutional differentiation and urbanization. The more a society's economy is based on industry rather than agriculture, the better educated its population and the more urban it is, then the more modern that society is considered to be. We can also view individuals in terms of whether they belong to a modern sector of society or they have exposure to modern influences (O'Leary 2001).

The secularization thesis lies within the broad theoretical framework of modernization. As part of this thesis, religious decline is predicted in response to the operation of features of modernization such as rationalization and societalization. Following Weber and his emphasis on the shift to rationality as part of the process of modernization, Bryan Wilson (1982) highlighted how the rational, scientific way of thinking of the modern individual would displace the religious way of thinking, undermining religious belief ranging from belief in the healing power of religious charms to belief in God. At the same time, societalization entails the enlargement of scale in society with a shift from living in small communities, typically the village, to living in cities. For Wilson, the small community, including the agriculturally based, is more conducive to religious belief and practice. In terms of the modernizationsecularization perspective we would hypothesize that persons who might be seen as less advanced along the modernization process - that is, older compared to younger, least educated compared to tertiary educated, farmers/peasants compared to whitecollar workers, and rural compared to urban - would all be more likely to be believers in religion.

The recent rapid modernization in China and the sharp shift from a statecontrolled to a more market-based economy and society in the post-Mao period have brought substantial material benefits to many citizens. However, they have also been accompanied by the break-up of rural communes and mass rural-to-urban migration, high unemployment and involuntary early retirement, the ejection of persons from the universal state health-care system and increased marital breakdown. Social dislocation may generate new spiritual questions (Fan 2003, 65) and quasireligious healing practices may give meaning to those who are displaced in the new economic order (Chen 2003, 199). Bays (2003, 193) draws attention to how the 
Christian magazine Tianfeng (Heavenly Wind) often prints articles or replies to readers advising them how to cope with the stresses of economic change and family problems. Therefore, persons from these dislocated and disadvantaged categories may search for comfort and so we may hypothesize that they will be more likely than persons in the socially advantaged or socially stable categories to be believers in religion.

There are additional categories or persons, such as women and ethnic minorities, who do not so neatly fit into a general designation as less modernized or more socially dislocated. However, in spite of state-sponsored gender equality, women in China tend to be more disadvantaged in socio-economic positions and, even among the city dwellers, they tend to be disproportionately vulnerable to unemployment and early retirement in the wake of economic restructuring, and less likely to find re-employment after being laid off. Ethnic minority groups tend to be concentrated in economically backward interior regions which remain socio-economically disadvantaged or have even declined in comparison with the rapid development witnessed by the coastal areas since the 1980s. Thus, international research on women and on ethnic minorities and ethnographic accounts for China would lead us to hypothesize that these categories too will be more likely to believe in religion.

\section{Methodology}

In order to address the research questions as outlined above, we use the China Values Survey conducted by Shanghai Academy of Social Sciences and Beijing University in 2004. This is a national representative sample covering 3,267 respondents aged 18 or over and resident in private households. The sampling instrument employed is that of satellite targeting, a new method increasingly used for government and academic research in China. The geographic coverage includes 65 counties in 23 (out of 30) provinces. The total effective response rate is 75 per cent.

To investigate the patterns of religious belief in China, we use the question ' $n i$ xing jiao ma?' (Do you believe in religion?), as noted above. This is a dichotomous variable used in descriptive and modelling analysis. We also use a range of socio-economic variables (as earlier discussed) to address the modernization and secularization theses. As some of the explanatory variables such as sex and marital status are self-evident, we give a brief description below of the other explanatory variables as we constructed.

Age

We differentiate three age groups: $18-35,36-50$ and 51-70. The youngest group are those born and educated after China adopted the opening policy after the end of the Cultural Revolution. The middle group were mainly educated during the period after the founding of the new China and prior to the socio-economic restructuring that started in 1978 as a result of the adoption of the reforms. The oldest group was the least educated. 


\section{Education}

One important determinant of socio-economic attainment and religious belief is the level of education an individual has attained. Given that a very large proportion of people in China are peasants with low levels of formal education, we differentiated four groups: tertiary, secondary, primary and no education.

\section{Class}

We use a six-category variable for class to reflect the social realities in China. As is well documented, China has a large agricultural sector. Many city dwellers were forced to take early retirement or were laid off. A large number of people turned to self-employment either as a result of forced redundancy or as a means to economic prosperity. The six categories were based on the occupational status of the respondents at the time of interview: (1) salariat (professionals and managers); (2) routine nonmanual or manual workers (the former consisting mainly of junior office clerks or sales/personal service workers in commerce and service sectors, and the latter of manual workers in industry and commerce); (3) retired; (4) petty bourgeoisie (sole traders or small employers); (5) the unemployed/laid off/never worked; and (6) peasants/farmers.

\section{Urban-rural (Hukou)}

A unique feature of China is the household registration system (hukou in Chinese). Although this system has relaxed somewhat in recent years, it still plays a very important role in people's lives, especially when people with rural hukou wish to live and work, and to have their kids educated in big cities such as Beijing or Shanghai. Since the 1980s millions of peasants have migrated to cities to find work. A threeway variable is created: (1) urbanite; (2) migrant worker; and (3) rural.

\section{Results}

The Percentage of Believers in Religion

Table 4.1 shows the association between socio-cultural-demographic attributes of the individual respondents and whether they believe or do not believe in religion. At the bottom of the table we see the result that 11.4 per cent reported that they believe in religion. This is a modest percentage and, as we discussed earlier, it is likely to be an underestimation of the percentage that have some religious beliefs, especially beliefs in Chinese folk religion. It is closer to official government figures than to the much higher non-governmental estimates, and the distinction between a narrow and a broader definition of believing in religion may account for much of the discrepancy. The percentage is also much lower than that reported for even the most irreligious of the post-Communist countries of Eastern Europe (Need and Evans 2004). 
Table 4.1 Believing in religion by socio-cultural-demographic factors (percentage by row)

\begin{tabular}{|c|c|c|c|}
\hline & $\begin{array}{c}\text { Believe in religion } \\
- \text { yes }\end{array}$ & $\begin{array}{c}\text { Believe in religion } \\
- \text { no }\end{array}$ & $\mathrm{N}$ \\
\hline \multicolumn{4}{|l|}{ Age } \\
\hline $18-35$ & 12.5 & 87.6 & 1,225 \\
\hline $36-50$ & 11.3 & 88.7 & 1,237 \\
\hline $51-70$ & 10.9 & 89.1 & 805 \\
\hline \multicolumn{4}{|l|}{ Sex } \\
\hline Male & 9.7 & 90.3 & 1,574 \\
\hline Female & $13.4^{* * *}$ & 86.6 & 1,693 \\
\hline \multicolumn{4}{|l|}{ Education } \\
\hline Tertiary & 8.8 & 91.2 & 350 \\
\hline Secondary & 10.6 & 89.4 & 1,632 \\
\hline Primary & 11.7 & 88.3 & 486 \\
\hline None & $15.3^{* *}$ & 84.7 & 799 \\
\hline \multicolumn{4}{|l|}{ Class } \\
\hline Salariat (Professional/Manager) & 7.5 & 92.5 & 290 \\
\hline Routine non-manual or manual & 7.6 & 92.4 & 530 \\
\hline Retired & 7.8 & 92.2 & 314 \\
\hline Petty bourgeoisie & 11.6 & 88.4 & 136 \\
\hline Unemployed & $13.2^{*}$ & 86.8 & 227 \\
\hline Farmer/peasant & $14.4^{* *}$ & 85.6 & 1,770 \\
\hline \multicolumn{4}{|l|}{ Marital status } \\
\hline Single & 11.3 & 88.9 & 427 \\
\hline Married & 11.4 & 88.6 & 2,650 \\
\hline Separated/Divorced/Widowed & $16.4^{\dagger}$ & 83.4 & 190 \\
\hline \multicolumn{4}{|l|}{ Health } \\
\hline Good & 9.3 & 90.7 & 640 \\
\hline Fair & $11.7^{\dagger}$ & 88.3 & 2,541 \\
\hline Poor & $26.4^{* * *}$ & 73.6 & 86 \\
\hline \multicolumn{4}{|l|}{ Ethnicity } \\
\hline Han & 8.9 & 91.1 & 2,903 \\
\hline Minority ethnicity & $33.6^{* * *}$ & 66.4 & 364 \\
\hline \multicolumn{4}{|l|}{ Urban-rural (Hukou) } \\
\hline Urbanite & 8.3 & 91.7 & 1,295 \\
\hline Migrant worker & $14.5^{* * *}$ & 85.5 & 394 \\
\hline Rural & $14.1^{* * *}$ & 85.9 & 1,578 \\
\hline All & 11.4 & 88.6 & 3,267 \\
\hline
\end{tabular}

Note: Weighted percentages and unweighted Ns. Each of the other categories in a variable is contrasted with the reference category listed in italics with significance levels shown for the differences in question: ${ }^{\dagger} \mathrm{p}<0.10 ;{ }^{*} \mathrm{p}<0.05 ;{ }^{* *} \mathrm{p}<0.01$; and ${ }^{* * *} \mathrm{p}<0.001$.

Source: The China Social Values Survey (2004). 


\section{Individual Characteristics Associated with Believing in Religion}

Who is more likely to believe in religion? Each of our individual characteristics or variables is presented separately with a test for statistical significance. Categories of a variable are contrasted with the reference category (in italics) and an asterix indicates differences which are statistically different. These tests allow us to be confident that the differences between categories of respondents are really to be found in the Chinese population and are unlikely to result from sampling error.

We see that there is no significant association between age group and believing in religion. There is, however, a statistically significant association between gender and believing in religion: only 9.7 per cent of males stated they believed in religion, whereas 13.4 per cent of females did. As regards education, only 8.8 per cent of respondents with tertiary education said they believed in religion, compared with 15.3 per cent of those with no education. This difference is substantial and statistically significant. Turning now to class-occupational category, only 7.5 per cent of respondents in the salariat (professionals/managers) said they believed in religion, compared with 13.2 per cent of those who are unemployed and 14.4 per cent of farmers/peasants. These differences, too, are substantial and statistically significant.

For marital status, although a higher percentage of persons who are separated/ divorced/widowed believe in religion than single people (16.4 per cent compared with 11.3 per cent), we cannot be confident that this difference is really found in the entire population as the result is not statistically significant. On the other hand, there is a clear association between self-reported health status and believing in religion. Almost three times as high a percentage of the persons with poor health (26.4 per cent) believe in religion compared to those with good health ( 9.3 per cent). This difference is highly statistically significant. However, we should note that persons who self-report their health as poor are a very small percentage of all respondents.

The results for ethnic group are clear. Over four times as high a percentage of those belonging to ethnic minorities (33.6 per cent) believe in religion compared to the majority Han Chinese ( 8.9 per cent). This difference is highly statistically significant. Finally, there is a statistically significant association between type of residence and believing in religion. While the higher percentage of believers among rural dwellers compared to urbanites - 14.1 percent as against 8.3 per cent - is not unexpected, the large difference between migrant workers at 14.5 per cent and other urban dwellers (with official urban residency) is striking. Migrant workers retained their ideological outlook and their even higher propensity for religious believing than their non-mobile peers in the rural areas might reflect the harsh socioeconomic situation they faced in the city and the concomitant socio-psychological dislocation.

Overall, the description of believers which is emerging is that they are disproportionately found among the following categories: females, persons with no education, farmers/peasants or the unemployed, rural dwellers or migrants, ethnic minorities, and those with self-reported poor health. This bivariate analysis is a useful first step in description, but it is inadequate for our exploration of the 
associations between individual attributes and believing in religion. It may be for example, that the relatively high percentage of believers among the persons with no education is because these are also the persons who are farmers/peasants. To try to unpack these complex multiple associations we now turn to multivariate statistical analysis. However, we will first provide some additional information about the religious composition of the believers in religion.

\section{The Religious Composition of Believers in Religion}

Of the 11.4 per cent of our respondents who declared they believed in religion, the largest single category of believing was Buddhism, amounting to 4.4 per cent of all persons in the survey. Less than 1 per cent reported that they believed in Taoism. This obviously underestimates the extent to which people may engage in some Taoist practices. It may also indicate the damage done to Taoism in particular by the suppression of religion (Lai 2003). A total of 2.5 per cent of all respondents reported that they were believers in Christianity (Protestantism). There were far fewer reported believers in Catholicism at 0.5 per cent. This looks about right as it is widely accepted that Protestants are about three times as numerous as Catholics. Finally, 3 per cent of respondents reported that they were Muslim believers. While these simple percentages may be of interest to some of our readers, we recall Chen's observation that there can be an undue interest in simply counting the number of believers $(2003,212)$. We are even more curious about who the believers are. Therefore, we wish to move on to our multivariate analysis of the characteristics of those respondents who declare they are believers in religion.

\section{Logistic Regression Coefficients on Religion by Socio-cultural-demographic Factors}

Logistic regression models are used to assess the relative importance of each of the socio-cultural-demographic characteristics while holding constant the other variables. The models use log odds ratios and therefore we report the coefficients of each category as against the base or reference category, holding constant all other variables in the models. If a category is equally likely to be a believer in religion as the reference category, then the odds ratio would be 1 and the log of the ratio would be 0 . Thus a positive coefficient means a greater and a negative coefficient a lesser likelihood of being a believer. The data are shown in Table 4.2, where we present two models. 
Table 4.2 Logit regression coefficients on 'believe in religion' by socio-culturaldemographic factors

\begin{tabular}{|c|c|c|}
\hline & Model 1 & Model 2 \\
\hline \multicolumn{3}{|l|}{ Age } \\
\hline $18-35$ & .000 & .000 \\
\hline $36-50$ & -.199 & -.063 \\
\hline $51-70$ & $-.332^{\dagger}$ & -.163 \\
\hline \multicolumn{3}{|l|}{ Sex } \\
\hline Male & .000 & .000 \\
\hline Female & $.280^{*}$ & $.336^{* *}$ \\
\hline \multicolumn{3}{|l|}{ Education } \\
\hline Tertiary & .000 & .000 \\
\hline Secondary & .017 & -.271 \\
\hline Primary & .029 & -.412 \\
\hline None & .258 & -.153 \\
\hline \multicolumn{3}{|l|}{ Class } \\
\hline Salariat & .000 & .000 \\
\hline Routine non-manual or manual & -.019 & -.033 \\
\hline Retired & .135 & .192 \\
\hline Petty bourgeoisie & .447 & .359 \\
\hline Unemployed & $.581^{\dagger}$ & .551 \\
\hline Farmer/peasant & $.655^{*}$ & $.606^{*}$ \\
\hline \multicolumn{3}{|l|}{ Marital status } \\
\hline Single & & .000 \\
\hline Married & & .087 \\
\hline Separated/Divorced/Widowed & & .412 \\
\hline \multicolumn{3}{|l|}{ Health } \\
\hline Good & & .000 \\
\hline Fair & & .181 \\
\hline Poor & & $1.084^{* * *}$ \\
\hline \multicolumn{3}{|l|}{ Ethnicity } \\
\hline Han & & .000 \\
\hline Minority ethnicity & & $1.594^{* * *}$ \\
\hline \multicolumn{3}{|l|}{ Urban-rural (Hukou) } \\
\hline Urbanite & & .000 \\
\hline Migrant worker & & $.756^{* * *}$ \\
\hline Rural & & .141 \\
\hline Constant & $-2.550^{* * *}$ & $-3.073^{* * *}$ \\
\hline Pseudo $\mathrm{R}^{2}$ & .020 & .088 \\
\hline Model comparison $\chi^{2}$ & & $163.440^{\mathrm{a***}}$ \\
\hline $\mathrm{N}$ & 3,267 & 3,267 \\
\hline
\end{tabular}

Note: Weighted percentages and unweighted Ns. Each of the other categories in a variable is contrasted with the reference category listed in italics with significance levels shown for the differences in question: ${ }^{\dagger} \mathrm{p}<0.10 ;{ }^{*} \mathrm{p}<0.05{ }^{* *} \mathrm{p}<0.01$; and ${ }^{* * *} \mathrm{p}<0.001$.

Standard errors and 95 per cent confidence intervals are not shown but are available on request. ${ }^{a}$ refers to terms in Model 2 that are additional to those in Model 1.

Source: The China Social Values Survey (2004). 
Model 1 in Table 4.2 shows that when age, gender, level of education and class are entered into the model as the independent variables, respondents who are female compared to male and those who are farmers/peasants compared to the salariat are both significantly more likely to report they believe in religion. As in Table 4.1 the asterix is used to indicate statistical significance. It is note-worthy that, while the "no education' category was shown in Table 4.1 to be significantly more likely than the tertiary educated to believe in religion when no other factors were considered, the significance disappears in this model when age, gender and class effects are taken into account. Similarly, the effect of being unemployed is no longer significant when these other variables are taken into account.

Model 2 adds marital status, health status, ethnicity and type of residency. At the bottom of Table 4.2, we show that Model 2 gives a significant improvement in fit over Model 1. We see that the coefficients for female and for farmer/peasant change only slightly and that both are still significant. We also now see that respondents who report poor health compared to good health, are minority ethnics compared to Han Chinese, or are migrant workers compared to urbanites, are all significantly more likely to report they believe in religion. Again, it is noteworthy that, while the rural category was shown in Table 4.1 to be significantly more likely than the urban category to believe in religion when no other factors were considered, the significance disappears in this model when our other variables are taken into account. It seems that what is important for believing in religion is being a farmer/peasant rather than simply being a rural dweller.

Therefore, some of the patterns suggested in our bivariate analysis in Table 4.1 are no longer present when we consider all the variables simultaneously in our Model 2. The categories of low level of education, being unemployed or being a rural dweller are no longer associated with believing in religion. What still holds is that females, farmers/peasants, those with poor health, minority ethnics and migrants are more likely to be believers in religion. Among these, it is minority ethnicity and health status which carry the greatest relative importance in terms of believing in religion.

\section{Discussion and Conclusion}

We turn now to the insights our results may provide us about the possible associations between modernization, social dislocation and disadvantage, and the reporting of believing in religion. We found no association between age group and believing in religion - neither reduced believing among the young which would be consistent with the prediction of both secularization and Marxist theories, nor an increased level of believing among the young consistent with the claims of religious revival and which might be expected given the increased tolerance of religious belief by the Communist Party. The absence of either an age effect or an effect for being 'retired' would also appear to belie the emphasis on greater religiosity among older and retired persons (for example, Luo 1991). We do not attempt to deny that many older people believe in religion, but we cannot claim that they are more likely to believe than younger people. The resolution here may be that there may be less difference 
between the age groups as regards believing in religion (as narrowly defined) but larger differences may be uncovered when examining religious practice.

A higher percentage of believing was found among the 'no education' category in the bivariate tables. This is consistent with claims of other commentators (for example, Kindopp 2004, 135; reported in Tamney 2005, 8). However, this may not necessarily be attributable to education per se. The association disappeared when other variables, including class, were taken into account in the multivariate analysis. Overall, the findings for level of education do not offer support to the modernizationsecularization perspective, which would expect the higher educated to be more nonbelieving. It is even possible that there is some under-reporting of believing among intellectuals. For example, Bays $(2003,193)$ advises us that, for intellectuals, to be known to be a religious believer would be detrimental to one's career. Here we should note that there is a difference between public proclamation of religious belief and anonymous response to a survey item.

On the basis of the multivariate analysis, rural dwellers are no more likely than urban dwellers to report being believers in religion, once class-occupational situation is taken into account. The absence of a rural effect would at first appear to belie the numerous ethnographic studies which highlight the association between rural dwellers and religion. While it is the case that there are many more places of worship in rural areas, including folk religion temples, and so practice may be higher, the levels of believing in religion (as narrowly understood in terms of Buddhism, Christianity or Islam) may not necessarily be higher. What is more relevant is whether or not the respondent is a farmer/peasant. The statistically significant result for farmers is consistent with a modernization-secularization perspective, although, overall, our results are rather indifferent to that perspective since being older and being less educated were not associated with being a believer.

Where we might extend the usefulness of the insight from the focus on modernization is to consider the impact of being in categories which may be viewed as disadvantaged and socially dislocated, and which may be a concomitant of that modernization. There is a positive effect on believing in religion for being a migrant. This is even more important for believing than being rural, once being a farmer has been taken into account. This is an interesting result as it contradicts the expectation under the modernization perspective that migration from the rural to urban environment would diminish religious belief. Given the extent of rural-tourban migration taking place in China under modernization, this represents a large and growing potential market for religious suppliers.

Having a self-perception of poor health is associated with being a believer. This is consistent with ethnographic studies on Chinese folk religion, quasi religious Qigong and Christianity where the attraction of faith healing is a prominent feature (Fan 2003; Chen 2003). Chen, in discussing healing sects in particular, describes how 'followers were drawn to the messages of inclusion where anyone could participate, especially those who had lost jobs or health care benefits' $(2003,199)$. If this reflects an appeal of religions more widely, then, as with the migrants, the appeal is to a socially disadvantaged group and their incorporation into the population of believers would shape the social composition of believers. However, we also note that, although we saw in the bivariate analysis that the unemployed were more 
likely than the salariat to believe in religion, there was no effect in the multivariate analysis once level of education was taken into account. Therefore, the higher level of believing in religion is not evident for all our categories of social disadvantage.

We found that ethnic minority respondents were much more likely to be believers. However, it is also interesting to note that, even among the minority ethnic respondents, only a third report that they believe in religion. This belies a tendency in the literature on religion in China which tends to equate minority ethnicity and being religious. The finding of higher levels of believing for women is consistent with numerous other commentators on a wide range of religions. It is also consistent with Feuchtwang's (2002) observation that there may be a feminization of both Buddhism and Christianity, at least in its congregational forms.

We are aware of limitations of our study - the respondent's own definition of religion available to us through our survey data is narrow. Further analysis for the different religious categories within the believing group is likely to reveal differences between the adherents of the various religions. Nevertheless, our present multivariate analysis has produced important new findings on religion across the entire Chinese population. We have identified particular categories of individual who are associated with believing in religion. These are women, farmers/peasants, ethnic minorities, persons with poor health and migrants. We have not found statistically significant effects for age or level of education and overall our findings do not lend themselves to a consistent explanation in terms of a modernizationsecularization perspective. However, there is more consistent support for the view that the believers are disproportionately drawn from some of the socially dislocated and disadvantaged categories in society. This has implications for the future growth and social composition of believers in religion in China.

\section{Bibliography}

Aikman, David. 2003. Jesus in Beijing: How Christianity is Transforming China and Changing the Global Balance of Power. Washington: Regnery.

Bays, Daniel. 2003. 'Chinese Protestant Christianity Today.' In Daniel Overmyer (ed.), Religion in China Today, Cambridge: Cambridge University Press. 182-198.

Bruce, Steve (ed.). 1992. Religion and Modernization: Sociologist and Historians Debate the Secularization Thesis. Oxford: Oxford University Press.

Chen, Nancy. 2003. 'Healing Sects and Ant-Cult Campaigns.' In Daniel Overmyer (ed.), Religion in China Today, Cambridge: Cambridge University Press. 199-214.

Crockett, Alasdair and Richard O'Leary (eds). 2004. Patterns and Processes of Religious Change in Modern Industrial Societies: Europe and America, Lampeter: Edwin Mellen Press.

Dean, Kenneth. 2003. 'Local Communal Religion in South-east China.' In Daniel Overmyer (ed.), Religion in China Today, Cambridge: Cambridge University Press. 32-52.

Fan, Lizhu. 2003. 'The Cult of the Silkworm Mother as a Core of a Local Community Religion in a North China Village: Field Study in Zhiwuying, Baoding, Hebei.' 
In Daniel Overmyer (ed.), Religion in China Today, Cambridge: Cambridge University Press. 53-66.

Feuchtwang, Stephan. 2002. 'Chinese Religions.' In Linda Woodhead, Paul Fletcher, Hiroko Kawanami and David Smith (eds), Religions in the Modern World. London: Routledge. 86-107.

Hunter, Alan and Kim-Kwong Chan. 1993. Protestantism in Contemporary China. Cambridge: Cambridge University Press.

Kindopp, Jason. 2004. 'Fragmented yet Defiant: Protestant Resilience Under Chinese Communist Party Rule.' In Jason Kindopp and Carol Lee Hamrin (eds), God and Caesar in China, Washington, DC: Brookings Institution Press. 122-148.

Lai, Chi-Tim. 2003. 'Taoism in China Today, 1980-2002.' In Daniel Overmyer (ed.), Religion in China Today, Cambridge: Cambridge University Press. 107-121.

Lang, Graham, Selina Chan and Lars Ragvald. 2005. 'Temples and Religious Economy.' In Fenggang Yang and Joseph Tamney (eds), State, Market and Religions in Chinese Societies. Leiden: Brill. 149-180.

Leung, Beatrice. 2005. 'China's Religious Freedom Policy: An Art of Managing Religious Activity.’ The China Quarterly. 184: 894-913.

Liu, Tik-sang. 2003. 'A Nameless but Active Religion: An Anthropologist's View of Local Religion in Hong Kong and Macau.' In Daniel Overmyer (ed.), Religion in China Today, Cambridge: Cambridge University Press. 67-88.

Lozada, Eriberto. 2001. God Above Ground: Catholic Church, Post Socialist State, and Transnational Processes in a Chinese Village. Stanford: Stanford University Press.

Lu, Paul Yunfeng. 2005. 'Helping People to Fulfill Vows: Commitment Mechanisms in a Chinese Sect.' In Fenggang Yang and Joseph Tamney (eds), State, Market and Religions in Chinese Societies. Leiden: Brill. 181-202.

Luo, Zhufeng. 1991. 'A Survey of Christian Retired Workers in a Shanghai District.' In Luo, Zhufeng (ed.), Religion Under Socialism in China. London: M.E. Sharpe. 195-202.

Madsen, Richard. 1998. China's Catholics: Tragedy and Hope in an Emerging Civil Society. Berkeley: University of California Press.

Need, Ariana and Geoff Evans. 2004. 'Religious Mobility in Post-Communist Eastern Europe.' In Alasdair Crockett and Richard O'Leary (eds), Patterns and Processes of Religious Change in Modern Industrial Societies: Europe and America, Lampeter: Edwin Mellen Press. 191-206.

O'Leary, Richard. 2001. 'Modernization and Religious Intermarriage' British Journal of Sociology, 52: 4. 647-665.

O'Leary, Richard. 2004. 'Modernization and Secularization' In Zhuo Xinping (ed.) Religious Comparison and Dialogue, [in Chinese] Beijing: Religious Culture Publishing House. 178-190.

Overmyer, Daniel (ed.). 2003. Religion in China Today. Cambridge: Cambridge University Press.

Potter, Pitman. 2003. 'Belief in Control: Regulation of Religion In China.' In Daniel Overmyer (ed.), Religion in China Today, Cambridge: Cambridge University Press. 11-31. 
Sun, Anna Xiao Dong. 2005. 'The fate of Confucianism as a Religion in Socialist China: Controversies and Paradoxes.' In Fenggang Yang and Joseph Tamney (eds), State, Market and Religions in Chinese Societies. Leiden: Brill. 229-253.

Tamney, Joseph. 2005. 'Introduction.' In Fenggang Yang and Joseph Tamney (eds), State, Market and Religions in Chinese Societies, Leiden: Brill. 1-18.

Wallis, Roy and Steve Bruce. 1992. 'Secularization the Orthodox Model.' In Steve Bruce (ed.), Religion and Modernization: Sociologist and Historians Debate the Secularization Thesis, Oxford: Oxford University Press. 8-30.

Wilson, Bryan. 1982. Religion in Sociological Perspective. Oxford: Oxford University Press.

Yang, Fenggang. 2006. 'The Red, Black, and Gray Markets of Religion in China.' The Sociological Quarterly, 47: 93-122.

Yang, Fenggang and Joseph Tamney (eds). 2005. State, Market and Religions in Chinese Societies. Leiden: Brill.

Zhang, Maogui and Lin Benxuan. 1992. 'The Social Implications of Religion: A Problem for the Sociology of Knowledge.' Bulletin of the Institute of Ethnology Academica Sinica, 74: 95-123. 
